Culture \& History Digital Journal 6(2)

December 2017, e012

eISSN 2253-797X

doi: http://dx.doi.org/10.3989/chdj.2017.012

\title{
When Hell is Other People. Interiority and Skepticism in António Lopes da Veiga
}

\author{
Fernando Rodríguez Mediano ${ }^{1}$ and Carlos Cañete $^{2}$ \\ ${ }^{1}$ Instituto de Lenguas y Culturas del Mediterráneo y Oriente Próximo-CSIC. Albasanz, 26-28, 28037 Madrid. \\ e-mail: fernando.rmediano@cchs.csic.es \\ ORCID iD: http://orcid.org/0000-0002-9432-6946 \\ ${ }^{2}$ Instituto de Lenguas y Culturas del Mediterráneo y Oriente Próximo-CSIC. Albasanz, 26-28, 28037 Madrid. \\ e-mail: carlos.canete@cchs.csic.es \\ ORCID iD: http://orcid.org/0000-0002-9714-0899
}

Submitted: 20 March 2017. Accepted: 10 July 2017

\begin{abstract}
The study of the process of construction of modern subjectivity offers an image of constant tensions between universality and particularity, which could be considered a manifestation of the conflictual nature of Modernity itself. As a way to solve the problems derived of the separation between universal and particular dimensions of this process -that has resulted in opposing interpretations regarding its confesional nature- a close study of the particular experience of the seventeenth-century thinker António Lopes da Veiga is presented here. This study is intended to provide some insight of the way in which similar intelectual concerns -of an international scale- over interiority and exteriority in epistemology, political thought, philology, theology and history, resulted in the constitution of a particular perspective regarding the individual.
\end{abstract}

KEYWORDS: António Lopes de Veiga; Modernity; Subjectivity; Universality; Particularity; Interiority; Exteriority; Skepticism.

Citation / Cómo citar este artículo: Rodríguez Mediano, Fernando and Cañete, Carlos (2017) "When Hell is Other People. Interiority and Skepticism in António Lopes da Veiga". Culture \& History Digital Journal, 6 (2): e012. doi: http:// dx.doi.org/10.3989/chdj.2017.012.

RESUMEN: Cuando el infierno son los demás. Interioridad y escepticismo en António Lopes da Veiga.- Los estudios acerca del proceso de construcción de la subjetividad moderna ofrecen un panorama de tensión constante entre lo universal y lo particular que puede considerarse como un reflejo de la propia naturaleza contradictoria de la Modernidad. Con el fin de resolver los problemas derivados de una separación entre las dimensiones universales y particulares de dicho proceso -lo que ha resultado en interpretaciones opuestas acerca de su naturaleza confesional- se plantea aquí una aproximación a la experiencia particular del pensador del siglo XVII António Lopes da Veiga. Este estudio pretende profundizar en la forma en la que el conjunto de preocupaciones -de escala internacional- acerca de la interioridad y exterioridad en la epistemología, el pensamiento politico, la filología, la teología y la historia, desembocaron en la constitución de una perspectiva particular acerca del individuo.

PALABRAS CLAVE: António Lopes da Veiga; Modernidad; Subjetividad; Universalidad; Particularidad; Interioridad; Exterioridad; Escepticismo.

Copyright: (C) 2017 CSIC. This is an open-access article distributed under the terms of the Creative Commons Attribution License (CC BY) Spain 3.0. 
The classic if somewhat controversial formula, $\mathrm{La}$ crise de la conscience européenne, as Paul Hazard put it in his groundbreaking book (Hazard, 1935), alludes to the long-term process of constructing and defining "consciousness". The relevance of this notion, therefore, is well beyond a simple allegorical effect of the book's title, since the emergence of a distinctive type of individual consciousness has been identified frequently as one of the main features of the emergence of European Modernity. However, at the same time, Hazard masterfully demonstrated the ambiguous and contradictory nature of that very notion. According to him, European Modernity is not only the expression of conciliatory and positive ideas but, also, a place for antagonizing and repressive views. Likewise, individual consciousness, as one of the central elements of this transformation, is not free from contradictions and tensions. Modern consciousness or subjectivity inhabits the distance between the interior and exterior, between subject and object. This gap is the battleground for the conflict between the affirmation of modern disciplining techniques and the emergence of a particular form of subjectivity whose agency was perceived as increasingly dangerous. This problematic or controversial context still exists as one of the fundamental obstacles to understanding how this emergence of modern subjectivity occurred.

Therefore, as a first step to unraveling the many conflicts underlying our understanding of this process, it is important to consider that the narratives regarding the emergence of modern subjectivity somehow reproduce the contradicting views of Modernity, as denounced by Hazard. First and foremost, narratives of modern subjectivity are marked by the tension between the interpretation of Modernity as a universal phenomenon and the particular character of its historical experience ${ }^{1}$. A recurring manifestation of this situation is the conflict between competing national or confessional narratives about the origins of modern subjectivity. It is common nowadays to situate the starting point of this controversy in the work of Max Weber. In his book The Protestant Ethic and the Spirit of Capitalism (1930), Weber argued that the Protestant -specifically Calvinist- form of spirituality was the basis for a progressive "disenchantment of the world", the modern development of critical thinking and individuality that ultimately also led to the development of the capitalist system of production and economic relations $^{2}$. It is necessary to bear in mind, however, that Weber was not original in his delineation of the origins of modern subjectivity. In fact, he was adapting a longstanding interpretation that situated Protestantism at the epicenter of modern rationalist and critical thinking, which can be traced back to early modern times and to the forefathers of that same intellectual genealogy ${ }^{3}$. It is revealing that replies to those claims can also be traced to that early date in the Catholic and, especially Spanish, context -as it was the case of the particularly difficult position of the novatores. This affirmation of the Catholic and Spanish role in the genealogy of modern thinking has continued ever since. Of special significance is the work of Marcelino Menéndez y Pelayo who by the late nineteenth century, before Weber, suggested an alternative genealogy of modern thought, in his work De los orígenes del criticismo y del escepticismo y especialmente de los precursores españoles de Kant (Menéndez y Pelayo, 1891), showing the connections between early modern Iberian authors and modern philosophy. In the mid-twentieth century, José Antonio Maravall continued the discussion, debating the Iberian roots of the modern idea of progress as well as many other ideas connected to it, such as the praise of literary originality and a critical stance towards the authority of tradition (Maravall, 1966). A particular version of this trend was also defended by Américo Castro who argued for the relevance of Iberian Jewish conversos in the development of modern thinking ${ }^{4}$. This position was more recently held by the late American historian of philosophy Richard Popkin, better known for his History of Scepticism, who was willing to demonstrate the Iberian roots of the revival of skepticism in the early modern period ${ }^{5}$.

The conflictual nature of these antagonizing narratives, as well as their continuation since Early Modern times, suggests that we should bear in mind Hazard's warnings over the extremely complex and pervasive nature of that ambivalence in the process of Modernity -and the emergence of modern subjectivity. A process including the affirmation of universal ideals constituted by the continuous affirmation of exceptionalism and particular identities. We should therefore be aware of the risk of reifying the limits of this process according to strict cultural or confessional categories but, also, of forgetting that confessional and cultural considerations were (and are) part of its fabric.

\section{BEYOND THE CONFESSIONAL LIMITS OF MODERNITY?}

In recent years there has been an increasing effort to provide a meaningful description of the genealogy of Modernity which would overcome the conflicts of traditional narratives. These contributions seek to overcome the confessional divide of previous antagonizing narratives of modernity by equalizing the relevance of each particular context -either Protestant or Catholic. Thus, the innovative nature of Protestant spirituality has been downplayed, pointing to the existence of medieval and pre-Reformation precedents (Eire, 2016: 937-938). Other contributions have focused on the troubles caused by a definition of these processes within each particular confessional context in contrast to its opposite. In this regard, the still frequent view of the Catholic context as the inverse of the Reformed one -which includes the use of such notions as Catholic Reformation or Counter-Reformation- has been denounced. Instead, they suggest that both contexts were experiencing parallel processes of adaptation to the same transformations in the early modern era: the emergence of the modern state, the discovery of new worlds geographically and in print, and the re-writing of history ${ }^{6}$. This awareness has led to the increasing adoption of more in- 
clusive perceptions of the relation between these two contexts and new terms such as "Early Modern Catholicism" have been proposed to overcome the antagonist logic of previous categories (Bireley, 2007: 146).

This preoccupation over terminology, however, was deemed insufficient by Simon Ditchfield who considered it a secondary issue in comparison to the dilemmas posed by the descriptions of the complexity and dynamism of these processes behind the affirmation of Modern Catholicism (Ditchfield, 2004). More recently, Ditchfield has argued for the need to animate the rigid vision of Early Modern Catholicism built on a monolithic image of the results and implications of the Council of Trent. While he similarly denounces this "confessio-centrism" in contrast to Protestantism in which this vision is construed, he also warns against the tendency to pre-determine this critique by imposing the narrative of "we too-ism", as an answer to the search for a place for Catholicism in the emergence of the Modern World. Thus, he argues, the legitimate response to "the curse of Max Weber" has led to the substitution of the weberian teleology by yet another, this time inspired by a simplistic interpretation of Foucault's ideas. To overcome this situation Ditchfield proposes an approach inspired by the work of Steven Shapin on the history of science, which tries to overcome the presentist and teleological narratives of modern scientific and philosophical transformations through the contextualization and embodiment of these scientific and intellectual productions. He defends that “'Tridentine Catholicism' needs to be understood less as an abstract noun [...] but rather as a concrete verb" (Ditchfield, 2013).

What Ditchfield highlights is probably due to the still frequent overdetermination of the definition of early modern processes according to -or in contrast to- the weberian model -and the Confessionalization Thesis derived from the works of Heinz Schilling and Wolfgang Reinhard. An example of this situation in the realm of literature on modern interiority is the work of Wietse de Boer regarding the system of social discipline in Borromean Lombardy (Boer, 2001). While adopting a Foucaultian approach, De Boer traced the development of a system of social discipline through the generalization of confession and penance as instruments of surveillance and control by the Post-Tridentine church. De Boer favored a vision of a conscious and instrumental reason -ostensibly championed by the Borromean archbishops- behind the emergence of these practices. The problem with this interpretation is that the analysis is overdetermined by the supposed intentions of those same authorities -which, in turn, overdetermines the confessional coherence of postTridentine church. According to this understanding, a predetermined confessional result is expected, and this is precisely why the disjunct between the supposed intentions of the authorities and the results of the process leading De Boer to state that "essential in [his] study is the distinction of intent and effect" (Boer 2001: 87). The problem with this perspective, as denounced by Ditchfield, is that by countering the protestant parochialism of the Weberian and Confessionalization Theses by exhibit- ing the muscular tone of the disciplinary system in Borromean Lombardy, it still fails to overcome the confessional divide by precisely reinforcing and predetermining confessional boundaries.

More recently, the example of Early Modern Iberia has provided a fertile ground to explore the constitution of modern subjectivity as a process that transcended confessional and cultural boundaries but, at the same time, resulted in the affirmation of collective (and individual) identities. Mass conversions in Early Modern Iberia, and the subsequent necessity to integrate those converted minorities, posed a tremendous challenge to traditional socio-cultural categories. Suspicion about the sincerity of the converts -whether real or imaginary- and the indeterminacy brought by the dissolution of religious difference resulted in the emergence of a general atmosphere of anxiety over individual and collective identity. This climate was a fertile ground for the proliferation of skeptical attitudes and doubt which permeated all aspects of life from everyday relationships to intellectual elaborations. In an effort to control these indeterminacies, new institutionalized narratives and devices were developed to control individual and collective identity. Instruments of discipline and surveillance sought the accurate definition of inner self. This institutional regulation of interiority, however, did not impede - and in fact many times fostered- the appearance of resistance and the proliferation of interiority as the locus of a conscious -critical- self. Hence, as it has been suggested, the Iberian context offers an additional perspective on the process of forming Modern subjectivity which has generally been overlooked in traditional narratives. Moreover, it is a view that goes beyond the confessional and cultural boundaries set by traditional approaches (García-Arenal, 2016).

Several works have already initiated the study of particular aspects of this context and, more importantly, have highlighted its cross-confessional dimension. Specially relevant are the works on the relational nature of alumbradismo (Pastore, 2004), the repercussion of Loyola's Spiritual Exercises (Sluhovsky, 2013) and the cross-cultural repercussions of the taqiyya -the islamic term for religious dissimulation- (García-Arenal, 2013). These works are all the more relevant since they have explored practices with broad implications for the emergence of inner religiosity, introspection, doubt, and self-criticism. The implications of those examples multiply if we consider how evangelization, discipline, and the regulation of manners, far from being practices restricted to particular cultural settings, had similar manifestations across the European context as well as those traditionally considered as colonial contexts ${ }^{7}$, which has led to confirm a continuity in the proliferation of similar disciplinary systems in all those situations (Prosperi, 1996: 551; Ditchfield, 2013: 30; Cañete and Torres, 2017).

All these works have certainly contributed to a more profound understanding of the multiple and contradictory dimensions of the process of constructing modern subjectivity. Overall, we consider a fundamental conclusion of these efforts to be the overcoming of confessional determi- 
nation of this process -centered in Protestantism, as a reaction to it, or focused in religious minorities- which must also be accompanied by a permanent consideration of the ways in which this process actually stimulated the formation of those confessional boundaries and individual identities. Hence, this situation is not distinct from any responsible approach to the wider phenomenon of Modernity, which constantly exhibits universal and particular manifestations that permanently challenge and reinforce each other. In the case of the formation of modern subjectivity, it is also relevant to consider that self-fashioning had collective as well as individual manifestations. This ambivalent nature creates a perfect environment for the proliferation of forms of coercion and discipline but also a space for interior affirmation and resistance. This context makes it even more necessary to explore ways to represent this Janusfaced reality. How could we comprehend this complexity?

Other authors have offered models to define this ambivalent reality. It is the case of the german sociologist Norbert Elias (2000), who in his major work about the civilizing process proposed a model that considered both the social and individual dimensions of disciplinary systems. The notion of the civilizing process, through the study of Early Modern courtly regulations of manners, also sought to provide an explanation for the formation of a universal social tendency in self-discipline and, simultaneously, of the particular national formations in which this process resulted. From the perspective of intellectual history, Richard Popkin presented his History of Scepticism (Popkin, 2003) as a narrative in which skeptical attitudes where a common denominator of both religious and anti-religious authors, Protestant and Catholic, old and new Christians. According to him, skepticism, as a fundamental characteristic of modern thought, was not the product of a particular confessional context but, rather, was the emerging result of a polemical dynamic and, hence, simultaneously, contributed to the affirmation of each confession, the questioning of the rest of them and, ultimately, all of them.

We certainly think that there is an undeniable crossconfessional dimension of the processes of Modernity, and -particularly in its intellectual dimension- of the emergence of modern subjectivity. As Stuart Clark has argued, there were themes and mechanisms (rhetoric, casuistry) that recurred in the formation of modern consciousness in Protestant and Catholic contexts alike (Clark, 1997: 6465 ). Prudence also became a major common denominator of self-fashioning attitudes in those contexts (Martin, 1997). However, while we completely endorse that there was a continuity of interests or, rather, concerns and preoccupations that resulted in similar responses across confessional boundaries -which could be considered a "field of problems"-, we also believe that those ideas also affirmed particular positions, either individual, social, political, or confessional. Therefore, a close regard to the intellectual formation of modern consciousness would offer a complex image of tensions between the universal and the particular, the social and the individual, the authority and the subversive. We believe that to explore what is beyond confessional and social limits in the modern construction of subjectivity it is necessary to understand how those transgressions were always the product of particular experiences, which is precisely what made them examples of self-assertion. This is why, as the axis for such a survey, we suggest the example of a particular author who experienced the raw historicity of those tensions as a conflict between interiority and exteriority in his courtly milieu. This author is the Portuguese António Lopes da Veiga (or López de Vega), undeniably one of the most radical skeptical thinkers of seventeenth-century Iberia.

\section{THE LONE MAN WHO LAUGHS}

The dialogue between Heraclitus and Democritus has enjoyed a long literary and philosophical life. The contrast between the weeping philosopher and the laughing philosopher illustrates different levels of discursive tension: from the likelihood of a more-or-less personally-engaged social criticism to the formulation of a radical disenchantment with the misery of the world, in which — as was Father Vieira's case - Democritus's laughter is nothing more than another form of lamentation (Vieira, 2001); from the topical illustration of physical characteristics and character traits linked with the bodily humours, to a finely shaded discussion of serious epistemological problems (García Gómez, 1984). This last was the case of Montaigne - a key figure in adapting ancient problems of Greek skepticism to modern philosophical thought when he invoked Democritus and Heraclitus in dealing with the problem of phenomenon and appearance, and its rule in the discursive regime of truth: objects can appear with distinct characteristics to different subjects (wine that is sweet to one person can be sour to another), and thus one can suppose that both characteristics belong to the object (Heraclitus), or that what is perceived has nothing to do with the essence of the object (Democritus). Despite Greek skepticism's varied interpretations of this point, Montaigne appears to integrate both solutions as part of the same problem, which leads in the end to a materialistic view of the phenomena: appearance, whether or not it has any direct relation to the object, is still a physical object which presents itself to us with its characteristics. Thus Montaigne opens up a problem which classical Pyrrhonism had managed to keep closed: 'the trap of the underlying worlds' ('le piège des arrière-mondes') behind the appearances (Paganini, 2008: 53), with its consequent tension between interior and exterior, practice and truth - a tension that produces a completely new elaboration of the ideas of truth and appearance. The result is an aporia which, in Montaigne's case, was resolved not so much by any original theoretical elaboration as by a reflective method of writing (Paganini, 2008: 55). Nevertheless, his work reveals skepticism's modern face, and gives an original shape to those aspects through which European modernity would lay hold of doubt as it grappled with the rift between appearance and reality - whether in terms of the subject's internal representation or of the cognitive relationship between subject and object through the phenomenal screen. Phenomena now acquired a complex 
value which no longer depended on the object but rather on the structure of the subject itself: an objectifiable phenomenon that can either be described in terms of its physical and mechanical manifestations, or else can be subjected to criticism in its dogmatic - such as moral or religious - aspects (Paganini, 2008: 59-60).

A radical expression of skepticism based on the net external-internal division can be found in one of those seventeenth-century Spanish works that recovered, in a more original way, the topos of the philosophers who laugh and weep: Heráclito y Demócrito de nuestro siglo, by António Lopes da Veiga or López de Vega. It is, in the opinion of Jeremy Robbins, one of seventeenth-century Spain's most original intellectual works (Robbins, 2007: 178-200). In his exposition of this book, Robbins highlights the skeptical principles which Lopes da Veiga explicitly claimed for his own: except for the divine truths known by faith, and mathematical demonstrations, nothing can be known with certainty, at least in the name of science (Robbins, 2007: 179). All the realms of the natural and human world are subject to such contingencies as to make any solid and rational knowledge impossible. Thus, Lopes da Veiga's Democritus aims his laughter at the natural philosophers and experimentalists, who believe they can derive knowledge from the facts they experience under conditions that are impossible to control (Robbins, 2007: 182). When he treats of classical philosophy, Democritus divides it into three schools: Dogmatics, Academics, and Skeptics. As Robbins points out, when Lopes da Veiga speaks of 'Skeptics', he is referring to the Pyrrhonists; in fact, at one point Democritus refers to himself as a Pyrrhonist. This is inexact, however, for he does not argue for a total avoidance of assertion but rather for the possibility of believing in something which, while not absolutely infallible, allows for a degree of "credible and probable" ("verosímil y probable") knowledge. This is a position proper to the Academics (Robbins, 2007: 180), which of course sends us back to the central problem of moral probabilism (Robbins, 2007: $187 \mathrm{ff}$ ). The methodological principles held by Lopes da Veiga were stated by Democritus: judgement should not be linked to the principle of authority but only to the "disenchanted light of [natural] reason" ("la desengañada luz de la razón"), which is "the sure, universal mother of all sciences". When in doubt,

free judgement [...] fits poorly with reflecting by faith on human things, and only the highest degree of probability discovered by its own speculations will allow it, in ambiguous matters, to be partial to this or that solution (Lopes da Veiga, 1641: 9-10). ${ }^{8}$

Natural reason, criticism of the principle of authority, skepticism, neo-Stoicism, probabilism: it is not always easy to find intellectual consistency with a philosophical tradition in this cluster of questions associated with Lopes da Veiga. Rather, one must explore the way in which he develops skeptical discourse in fields like political thought, preceptive poetics, or critical history.
For Lopes da Veiga, the act of "disenchantment" ("desengaño", lit. 'untricking', the state of being undeceived) produces the singular figure of the "Lone Man at Court", which he develops in the dialogues of the Philosopher and the Courtier, collected in Paradoxas racionales, a work he had completed in 1655, near the end of his life, and had prepared for publication, but which in fact was not published until 1935. The Lone Man at Court is the figure of the disenchanted Philosopher, initially a contrasting figure to the topical Lone Man of the Village. To retire to the city allowed him to live according to the dictates of reason without the discomforts of rural life, which is full of village people whose reason serves "only for personal gain and damage to others", ${ }^{9}$ where it is impossible to pass unnoticed or to escape the control of a society in which "everything is seen. Everything is noticed. Everything is spoken badly of"10 (Lopes da Veiga, 1935: 15); where every argument is founded on the principle of local authority, and 'in every conversation, what such-and-such a wise man said is taken as the voice of an oracle, and the proof of whatever is being discussed is what so-and-so said' (Lopes da Veiga, 1935: 15). ${ }^{11}$ Urban retirement as a space for the operation of reason is the first indication of the epistemological dimension of this topography, which constitutes (as we shall see) a central point of Lopes da Veiga's thought (Ocasar Ariza, 2015: 349-351), based on the net distinction between appearance and truth.

\section{HUMAN INEQUALITY}

The issue of human inequality was one of Lopes da Veiga's obsessions. It was the topic of the initial dialogues in Heráclito i Demócrito, and also of the second "Paradoxa" in his Paradoxas racionales, titled, "La diferencia de la sangre i de los nacimientos ni tiene verdad en la naturaleza ni es más que una vanidad ridícula al verdadero filósofo" ("The difference of blood and birth has no true basis in nature and is nothing more than a laughable conceit to the true philosopher') (Lopes da Veiga, 1935: 34ss). In this dialogue a philosopher and a courtier debate whether social inequalities have a natural origin. The courtier believes that birth in either a noble or a humble family is a matter of nature. In fact, nature itself manifests differences between species and between races within each species. To inherit blood from one's parents is, in the final analysis, a matter of nature also. The philosopher, answering these arguments, gives two reasons why inequality is not a question of nature: neither republics nor ministers nor princes have received the power from nature or its Author to "change and qualify" ("cambiar i calificar") blood; and not even nature or God himself could do that without at the same time changing the species (a radical and "modern" version of the problem of the extent of power and God's will at a time when the idea of nature was expanding conceptually). Lopes da Veiga underlines the radical separation between "natural law" and "civil law" or "political law", and adheres to the typical Tacitist idea of dual morality (Núñez, 2007: 87), although the consequences of this are not always of the 
same sort. In Heráclito i Demócrito, Lopes da Veiga connects "natural law" to the myth of the Golden Age invoked by the poets, when human equality was supposed to have existed. But it is useless to give credit to such a myth once inequality, with its nobility and monarchies, has entered History ; rather, one must accept it with a view to preservation, although the wise person knows in his heart that social distinctions and values linked to honour have nothing to do with truth:

It is not a type of flattery to accept, in political terms, what political law has been able to furnish for the purpose of good government. Thus one ought to laugh internally in agreement with the natural law that makes everyone equal, while externally accommodating oneself to the civil order that establishes differences. And this distinction holds true, both in what is felt and in what is manifest, even though they seem to be contradictory actions (Lopes da Veiga, 1641: 15). ${ }^{12}$

This distinction between the exterior world of ceremonies and the interior world of truths has its counterpart in religion:

As for the others, be aware that, just as Religion has two types of worship, one internal and the other external, so the same division exists in human considerations and venerations. Internal veneration, I freely admit, is owed by the wise man only to either intellectual or moral virtue. But external veneration, so long as it is moderate (taking into account the custom of the world, which you alone are not sufficient to amend), is required of you by civil life and the need to preserve yourself (Lopes da Veiga, 1641: 13-14). ${ }^{13}$

If Democritus criticises those who invoke a Golden Age of natural human equality, and calls for respect for the social hierarchy as a means of maintaining political order, the Paradoxas racionales seem to show a preference for the philosopher's disenchantment in the face of the "falseness" that comes from the "showiness in haughty ostentation" ("figurería en las ostentaciones endiosadas") of those who take their noble birth seriously, in a ridiculous spectacle from a farce or comedy (Lopes da Veiga, 1635: 41). The different ways that people ought to be treated in accordance with their social status can be imposed by "the political government or the style of each province [...] but the wise and disenchanted person will reserve internally a right knowledge of the truth of each one's essence", ${ }^{14}$ accommodating himself, as regards externals, to what he cannot change or reform (Lopes da Veiga, 1635: 41-2). Criticism of aristocratic values linked to lineage and honour ("the maddest form of tyranny", "la tiranía más loca") becomes even more radical when speaking of the military profession,

so glorious according to political reason but, according to natural reason, a brutality unworthy of humans. And military valour, according to this same judgement, ought to be called bestial savagery rather than valour (Lopes da Veiga, 1635: 76). ${ }^{15}$
In criticising wars, he places most of the blame on kings or a few free republics which,

not content with subjugating the bodies of their subjects, have extended themselves to wishing to subjugate their minds as well and persuade us that we ought not only to obey and serve them with our bodily members but even with our reason, giving the same credit to their decisions that they give to divine ones, even to the extent of repudiating the latter and the natural law on which they are based (Lopes da Veiga, 1635: 86). ${ }^{16}$

In this sense the Paradoxas racionales appears to be the counterpoint to El perfeto señor, a political work in which Lopes da Veiga describes, not the interior vision of the disenchanted man, but what external practice of political government should be. In this work he recommends, for example, different ways of treating people according to their condition and the public good (Lopes da Veiga, 1653: 28-36). In some sense, Lopes da Veiga appears to offer in his writings a tri-part position with regard to the political problem of the separation between the interior and the exterior, or natural and civil law: the position of him who stands within the logic of governmental practice, as in El perfeto señor; the position of the disenchanted philosopher who knows the natural reality below the laughable social conventions, and who, in the Paradoxas, sees the interior life of the wise person retired at court as the place of truth; and finally the position of Democritus, who laughs at the illusions of natural equality that expect to transform the hierarchical and political order, and who adopts a cynical skepticism regarding the possibility of bringing together the natural and political laws. One might say that each of these positions is a response, not to the ridiculous external "reality", but to the ways in which the subject arranges and sees himself with respect to that external "reality". As in Montaigne's case, the aporia of the idea of the "arrière mondes" consists of creating a strong idea of the materiality of the phenomena, which de facto loses its merely illusory character and becomes the horizon with which the various possible forms of subjectivity align themselves. This is a crucial point, constituting - as Paganini has indicated — one of the ways that Stoic philosophy and Greek skepticism were recovered by Modern Europe. It also forms a central axis for the expression of the moral problem made explicit by Lopes da Veiga's epistemological scheme, as Robbins says; namely, the notion of probabilism, which is the key element informing a good part of the political, scientific, and historiographical debates of the period.

\section{LITERARY DISPUTATIONS}

For Lopes da Veiga, a literary disputation was the only occasion when a philosopher who was retired at court ought to set aside his modesty and the solitude of his retreat. His sixth "Paradoxa" is titled, "En las contiendas literarias, más desayuda que aprovecha la modestia, $\mathrm{i}$ el que no se hiziere temer con el modo no se hará estimar 
con la sustancia" ("In literary contests, modesty is more a hindrance than a help, and he who does not make himself feared by his manner will not be esteemed for his substance") (Lopes da Veiga, 1635: 125). A learned person ought to be more feared than loved, and should provoke such fear in his adversaries that they will not dare to speak in his presence. Here the notable interior-exterior separation acquires a new meaning in Lopes da Veiga's discourse: if someone does not dare to dispute publicly with a learned person, the motives for such reluctance - being convinced by the other's argument; fear of being made to look a fool - matter little. What truly matters is external respect; those who witness the dispute "do not guess at nor pay attention to motives". In order for one to acquire respect, "in controversies there is no means more à propos than to make oneself feared, whether by being known for one's self-suffiency, or by the sharpness of one's replies, or by one's belittling of objections" (Lopes da Veiga, 1635: 128). ${ }^{17}$ This is an argument that puts utility above honour or reason, and which Lopes da Veiga derives from his personal experience as a controversialist in the "depraved" Spain of his time, with its abundance of "people who are taken to be oracles by everyone who speaks to them, for no other reason than that they give solutions confidently and treat those who contradict them with scorn" (Lopes da Veiga, 1635: 129)..$^{18}$ In literary disputes, to seek to be loved by others is a sure way of being despised, because what everyone truly loves is his own opinion. Lopes da Veiga was an experienced man in the literary and courtly environment of seventeenth-century Spain. There he had tried with varying success to make a career for himself, from his role as secretary to Bernardino Fernández de Velasco to his quest for the generosity of protectors such Manuel Álvarez Pinto y Ribera or Francisco Fernández de la Cueva (Acquier, 2000). The already-mentioned vicissitudes of his political thought and ways of interpreting the distance between civil and natural law have been the subject of a variety of interpretations; they could perhaps be integrated into the evolution of his courtly and academic career, and the varied consciousness of the separation between "mode" and "substance" which, in different ways, permeates the whole of courtly literature (Acquier, 2000: passim ). The dialogue genre, while always recalling classical models such as Cicero, underwent a radical change throughout the Early Modern Period, reflecting conditions of new literary and courtly institutions of sociability, in which the rules of communication were substantially transformed. Doubt was no longer a tool of argument, used in the dialogue as a maieutic technique for eliciting the truth; rather, it was now shown to be a solvent attacking forms of constructed authority, a tool of the reasoning power that acted on the basis of the new concept of distance between exterior and interior (Ong, 1958).

António Lopes da Veiga knew the world of literary controversies well; he participated in it keenly and even organized debates at his house (Sánchez, 1961: 123-134). From his retirement at court, the Philosopher of the Paradoxas racionales describes such controversies in negative terms, taking a position that eludes "the ordinary competitions, gatherings, academies, and courtly congregations" 19 which, in Spain, unlike other countries, had become "a terrible battleground, a perpetual iron-worker's shop of thundering voices and controversies," where conceit and arrogance predominated, and which were more like battles than places where "truth is investigated". In the end, they were "gatherings of different hierarchies of "men of understanding', not all of them refined by studies, but rather a mix of drones and worker bees; of ignorant men to whom 'good reason' was attributed, and experts $[. .$.$] ". { }^{20}$ This hierarchy is made up of diverse classes: those who lack an education, who "learn some principles in that place which they would be better off not to have heard, and, using them, intrepidly enter into any topic that is proposed," 21 employing without rhyme or reason the "little reasons" they heard "the day before"; and the meek ignorant men "who listen and are silent when points of science are argued", 22 who look for recognition by a different means, whether by "grace and elegance", or "jests and witticisms, most of the time consisting of the sudden twist of a double meaning". ${ }^{23}$ The educated men, finally, lacking in modesty, "go ahead and decide that whatever their proposal might be is a matter of faith, while condemning all the others as heresy", ${ }^{24}$ which results in a "hubbub of voices and Babylonian confusion" 25 in which - unlike in other countries - all that is sought is "a show of superiority either in one's studies or one's cleverness" (Lopes da Veiga, 1935: 20-23). ${ }^{26}$ One might compare the sarcasm with which Lopes da Veiga's Democritus treats literary meetings with the happiness shown by Manuel de Faria y Sousa's Democritus when spending all his money travelling the world searching for conversation with other men (Sosa, 1674: 28). The same impulse that in the latter showed itself in a hope of human communication through dialogue, in Lope da Veiga has become a radical disenchantment with social institutions and courtly rhetoric.

In Lopes da Veiga, this type of meeting, of the sort that was common in the Madrid of his day, had at least two dimensions: on the one hand, its social aspect, in which literary controversy marked out a space of courtly sociability. There, along with literary and erudite arguments, those in attendance spoke about: "What places and types of employment have been given out or appear likely to be given out again? What places in public government are the most prestigious and the most worthy to be sought after? What styles are observed in the law courts?"27 and other such issues of court politics (Lopes da Veiga, 1935: 28). Lopes da Veiga's critiques of academic meetings are counted among the most radical of the seventeenth century (King, 1963: 99). In relation to this central collection of concerns it is possible to establish an additional link to his political thought: let us not forget that Lopes da Veiga was secretary to the Condestable Bernardino Fernández de Velasco, an important figure in reorganising the management of documents in that noble house, and who had a high notion of the political dimension of its archive, its history, and its literary culture as they were connected to the construction of his lineage's memory. 
On the other hand, the literary meetings also had an epistemological dimension. It is possible to fit Lopes da Veiga within a cultural shift that radically affected the function of the dialogue as a dialectical expression of a certain regime of truth. This is a commonplace of "modern philosophy". For example, Robert Boyle, in his ferocious criticism of the culture of scholastic dialectic, wrote:

[...] the litigious philosophy of the schools seldom furnishes its disciples with better than dialectical or probable arguments, which are not proper, either fully to satisfie the person that employs them, or leave his adversary without any answer, plausible at least, if not full as probable as the objection; upon which account, men that have more wit than sincere love of truth, will be able to dispute speciously enough [...] (Boyle, 1690: 46).

In Lopes da Veiga's own words, this is a criticism of those who, lacking education and arguments, prefer to lay hold of "flattery and forceful boldness" ("la carantoña $i$ de la violencia del descaramiento"); people who respect nobody and whose success is owing to the fact that,

since the questions usually raised for discussion are the sort that cannot be demonstrated mathematically, a clever person will always find a means of escape, and even a means of attacking the most accepted conclusions of learned men" (Lopes da Veiga, 1935: 22).28

The "mathematical demonstration" alluded to here expresses the reach and limits of the speculative method. As to its reach, the mathematical system is the proper means of expression for the true sciences, because it is the only one that is accurately demonstrable. Beyond mathematics, that which can be known with certainty is so slight that it is equal to nothing, and therefore useless:

To speculate about the secrets of Nature, the Causes and Effects of all that the Universe contains, is undeniably praiseworthy to the extent that it represents the curiosity of the Understanding and the exercise of the Mind. But to make it one's principal occupation, to hang one's reputation, or loss of it, on this, given the uncertainty of all its conclusions and the little usefulness that follows from such Study, is not only, in my opinion, unworthy of praise, but is a most undignified and laughable objective no matter how one looks at it (Lopes da Veiga, 1641: 225-226). ${ }^{29}$

This skepticism with respect to the possibility of establishing sure knowledge about things is the reason why he calls himself a "Pyrrhonist". Once one moves beyond the limits of sure mathematical knowledge, the only valid criterion is utility, which is understood as the governing and preserving of life. For this reason, the true philosopher should dedicate himself to searching for what is most useful, not to theoretical speculation. As his Democritus says: "I call 'wise', not the most speculative person, but the one who knows what is most to his advan- tage" (Lopes da Veiga, 1641: 337). ${ }^{30}$ For this reason the education of philosophers should include some mathematics, enough to allow for "interacting and conversing" ("el trato y las conversaciones"), and a few rudiments that can be used in commerce or for making purchases in the marketplace, for music, or for eventually dedicating himself to building fortifications or other practical activities. Speculative wise men like Anaxagoras or Thales abandoned the search for utility in favour of speculations, and for that reason one lost his property and the other fell into a pit (Lopes da Veiga, 1641: 337-8).

\section{HISTORY, GRAMMAR, AND CRITICISM}

History also lacks that utility that classical thought had given it as life's teacher and prudence's staff. A staff, Democritus says ironically, is only good for the lame or the feeble (Lopes da Veiga, 1641: 197). History is a human work, and as such is subject to all sorts of passions. It is impossible to find among humans unvarying information about the same acts. Beyond a few general facts that everyone knows, no single truth about human history can be established. History's authority derives from the fact that it is presented in printed form and arranged by chapters (Lopes da Veiga, 1641: 198-9); one might say that its authority depends on its appearance of authority. For the rest, those who invoke the usefulness of history for human government have never really learned anything solid about history. On the contrary, the naturally perverse person learns from history "to know the defects of other people's lineages" or to "support those of his own." 31 The historian, pulling a single thread, weaves a discursive plot that transforms news into Science in order to dazzle the ignorant (Lopes da Veiga, 1641: 199). ${ }^{32}$ In the final analysis, a prudent man can derive a certain amount of useful teaching from historical documents to satisfy his own curiosity or in aid of his public responsibilities, "even so, abstracting it from the truth or falsity of the accounts",33 but in general the humanities only serve people of "vain showiness, if not evil curiosity" (Lopes da Veiga, 1641: 201). ${ }^{34}$

The accusation of useless speculation that Lopes da Veiga launches at Natural Philosophy returns in rawer form when he attacks the "arrogant crowd of Grammarians and Critics [...] the ignorant rabble and dung [...] of the literary men". ${ }^{35}$ Grammar, interested only in the names of things, is concerned with the first and second instruments of the sciences, and creates authority "about letters, syllables and words, without which it is impossible to write or speak; authority with the power to insult or approve the images and expressions of concepts, if not the concepts themselves, and to fill in or amend the most authentic texts"; 36 a childish study, in other words, "incapable of penetrating to Wisdom's interior", ${ }^{37}$ while giving its practitioners "the sovereignty over externals" (Lopes da Veiga, 1641: 131). ${ }^{38}$ It is an ostentatious and pompous knowledge, which triumphs at court; based, not on the use of reason, but on the principle of authority, which leads them to accumulate citations of authors instead of thinking for 
themselves. In reality, it is an insubstantial knowledge, limited to establishing an expression's propriety or impropriety, "vocabulary meanings, the pronunciation and accenting of words, the spacing of syllables, assonances and dissonances, the sibilance or silence of letters" (Lopes da Veiga, 1641: 135). ${ }^{39}$ In dedicating themselves to the sciences' first principles, grammarians exercise "a perpetual beginner's profession", 40 standing "fixed and permanently at the threshold of the door of knowledge" (Lopes da Veiga, 1641: 134) ${ }^{41}$, with no ability for "disputing and recognising the inner nature of opinions, questions, and scientific discourse" (Lopes da Veiga, 1641: 135). ${ }^{42}$ The Critics' knowledge is like the Grammarians': "to correct corrupted words, modify collocations, approve or reject the readings of citations" are tasks "that do not go beyond the region of words" (Lopes da Veiga, 1641: 138). ${ }^{43}$ Critics - unlike Expositors (who interpret necessary books and determine the best readings for important citations) - are not occupied with the major Sciences, but with a miscellany of the poetical, the historical, and matters of no usefulness (Lopes da Veiga, 1641: 138); they "denaturalise the essence and qualities of each thing, making the object to be the instrument, and the instrument, the object" (Lopes da Veiga, 1641: 138-9) ${ }^{44}$ Here, once again, the interior-exterior fissure has taken on a sociological as well as an epistemological value: externals consign us to superficial knowledge; internals lead to the higher sciences, whose methodological model is mathematics.

\section{A FIELD OF PROBLEMS}

Lopes da Veiga's thought directs us to an intellectual field where epistemological, political, literary, and moral problems intersect on the basis of a strong distinction between interior and exterior. Lopes da Veiga appears to place his own intellectual horizon outside Spain, particularly when he alludes several times to places where, unlike Spain, "men learn through disputation, and they dispute in order to learn the little that can be known" (Lopes da Veiga, 1935: 24). In fact, as has already been written (Robbins, 2007), it is not hard to place Lopes da Veiga's work within the context of European skepticism, which during those same years was producing key works by Descartes, La Mothe Le Vayer, Gassendi, and Pascal, and whose outstanding representatives in the Iberian tradition included Pedro de Valencia and Francisco Sánchez. The allusion to "Pyrrhonism" was not simply a reference to classical philosophy, but an intellectual context in which the epistemological and methodological problem had a central effect on political and theological thought, on the order of the knowledge disciplines, and on the theory of representation. In order to place Lopes da Veiga within this intellectual context, it would be enough to recall how the method of "rational paradoxes", which attempted to use reason to show that common sense was nonsense, goes back to a tradition that was to be instrumental for the skeptics of the first half of the seventeenth century. One might recall what La Mothe Le Vayer said about his own paradoxes and the way in which philosophical thought contradicts the "sentiments ordinaires \& des opinions reçeuës" (La Mothe Le Vayer, 1630: 203). For his part, Pierre Gassendi first published his Exercitationes paradoxicae in 1624, expounding the foundations of his own skeptical, Pyrrhonic, and anti-Aristotelian system of logic, whose first stage is expressed in paradoxical form. As is known, Gassendi's attack on Aristotelian logic had as its starting point the problem of truth and appearance. From his typically skeptical and Pyrrhonic viewpoint, it was impossible to transcend appearances and make a solid judgement about interior truth. Using this principle, Gassendi launched his devastating attack on Aristotelian and scholastic logic and syllogistic, which were definitively impotent in the face of vera rerum natura; the "paradoxes" serve to illustrate the blind spots of Aristotelian logic and dogmatic science. For Gassendi, the exit from the skeptical cul-de-sac was found in a subsequent recourse to Epicurus, which allowed him to bring in the possibility of forming ideas based on the senses, and an insistence on making judgements based on ideas tested experimentally (Jones, 1981). In this sense, the radical skepticism of Lopes da Veiga had an anti-experimental side, which depended on a radical mistrust of the possibility of deducing any sure knowledge from appearances; an intellectual pessimism that Lopes shared with, for example, Gracián (Robbins, 197).

Here we can observe one of the limits of Lopes da Veiga's thought as regards epistemology. When he invokes mathematics as the only method for the major sciences, he does so in the context of a major polemic concerning the status of mathematics as a science. In Aristotelian tradition mathematics were largely outside the canon of logic, and therefore outside the regime of truth. Although late neo-Aristotelian tradition attempted to include mathematics as a form of knowledge, it did so in a way that did not relate it to the natural world; in other words, the truth of the mathematical method was limited to mathematical entities, which were themselves "unnatural". The demonstrative character of mathematics within that Aristotelian tradition was thought to be inadequate for determining the causes of things and the knowledge of essences. This was the dominant tradition, for example, in Portuguese universities during the seventeenth century (Carolino, 2007). Lopes da Veiga, for his part, gives a central scientific status to the mathematical method, but he does not take the key step of making mathematics the central method of natural philosophy. One can compare, for example, Lopes da Veiga's view with Descartes' mention of mathematics in "Part One" of his Discours de la méthode:

Je me plaisais surtout aux mathématiques, à cause de la certitude et de l'évidence de leurs raisons; mais je ne remarquais point encore leur vrai usage, et, pensant qu'elles ne servaient qu'aux arts mécaniques, je m'étonnais de ce que, leurs fondements étant si fermes et si solides, on n'avait rien bâti dessus de plus relevé.

As we have seen, Lopes da Veiga, too, admired the certainty and evidential character of mathematical rea- 
soning, but he seems to have limited its usefulness to the "mechanical arts" and did not ask himself about "leur vrai usage"; that is, he did not take the fundamental step of linking mathematics to natural philosophy, precisely because of his skepticism with regard to any possibility of certain knowledge. This was, of course, a debate that was widespread in all Europe, in which the more radical skeptics doubted mathematical formalism. For example, this appears to have been the cause of the clash between Cremonini and Galileo: the extreme skepticism of the former was based on a concept of sensory knowledge drawn from the Aristotelian tradition that could not be subjected to mathematical formalism nor to the new scientific experimentalism. At the same time, that idea carried him to a radicalism greater than Galileo's with regard to crucial problems like the immortality of the soul; in many respects Cremonini was close to the atheism of Vanini, whom undoubtedly he had met, and was imbued with a Nicodemism very much like that of Lopes da Veiga - Intus ut libet, foris ut moris est - that was the foundation of a radical form of utilitarianism (Muir, 2008: 48-54).

The reclaiming of mathematics and the denunciation of rhetoric are two forms of setting out skepticism's crisis of interiority in representational terms. The beginning of 1656 - that is, around the time that Lopes da Veiga was writing his Paradoxas racionales - , was the date of Pascal's second "Provincial Letter", dedicated to the problem of sufficient grace. Trapped in a spider's web of arguments and debates among Dominicans, Jesuits, and Jansenists, Pascal found himself facing the dilemma that, no matter what terms he chose to adopt in the debate, he would end up being either a heretic, a Jansenist, or an outlandish man. The problem was that words (just sound, a movement of air) were not adequate to express substance: one might debate about the sound - or, what is the same thing, the word while the substance is something else. Ambiguous words, improper antitheses, unfounded metaphors: the traps of language (to call "insufficient" grace "sufficient") reduced problems to a question of rhetoric that ought to be subjected to criticism (Magnard, 1987: 13).

Lopes da Veiga, in his introduction to the Heráclito, gives an example of his loathing for philological criticism, explaining that, with regards to orthography, he had decided not to pay attention to "derivations from the Latin tongue nor from any other whatsoever from whence our words derive, but only to adjust my writing to how words are pronounced". In so doing, he was taking a singularly coherent position. Philological learning is only a superficial covering of dead leaves that does not correspond to the true meaning of things. The orthographic question was the subject of prolonged debate in Spain, and the defence of the position that words should be represented according to how they sound, not according to etymological tradition, can be found as far back as Mateo Alemán and Gonzalo Correas. The latter had a wellknown interest in orthography, which caused him to compose various treatises on the topic. In them, he followed Nebrija in arguing for the need to write the Spanish language as it was spoken, and to free it from the burden of etymology and of those who wished to write according to the Latin model (Galán Melo, 1992). These men, said Correas, made the Castilian language a slave to Latin when in reality Castilian was an ancient and better language than Latin (Korreas, 1630: 48). There are various ways of interpreting Correas's position. First, it is a defence of Castilian as an imperial language, in the style of Gregorio López Madera's defence. But this vision of the language also has moral implications; in fact, Correas published his Ortografia in 1630 together with the Enkiridión de Epíkteto, one of the means of introducing neoStoicism to Spain. In the dedicatory epistle to the Conde Duque de Olivares, Correas writes:

I present two Stoic philosophers to Your Excellency in the Castilian language; they are as well-adjusted in the costume of words and orthography as they were in their reasons and customs. This, the exterior, is my part; the interior is what their writings say [...]. They are joyful in their robe and clothing, as frugal and simple as was their life. ${ }^{45}$

As with Pascal and Jansenism, there is a relationship between grammar, moral philosophy, and logic.

\section{HISTORY AND POLITICS}

As we have seen, the anti-experimentalism of Lopes da Veiga was based on the impossibility of reducing physical data to significant events in terms of knowledge. The impossibility of controlling data extended to his concept of politics and history: human actions cannot be reduced to a consistent form of knowledge because humans are subject to uncontrollable passions, and most of all because it is impossible to trust witnesses. Such diversity is wholly incompatible with the character of truth, which is singular; it makes it impossible to derive the same ends from the same causes. For the same reason, politics cannot be reduced to rules nor to a sequence of the laws of causality. At this point, some of the contradictions of Lopes da Veiga's utilitarianism become clear, when it reaches its conceptual limit with regard to his position on so-called políticos. Politicos had continually been the object of criticism, constantly accused by their enemies of being atheists (Gracián de la Madre de Dios, 1978: $327-$ 340; Campanella, 2004). Lopes da Veiga's discourse on Politicos closes with a disquisition on atheism, but in his case the development of the argument is unusual. The Politicos are those who put Reason of State ahead of every moral principle, and for this reason they prefer not to trust anyone else; they are men

so contrary to every type of Faith that they do not concede even to Divine Faith more than the unavoidable appearances necessary for its preservation [...]. They wish to examine higher things with the same eyes they use to look at earthly things. ${ }^{46}$

Thus the Politicos study the principles, motives, and rites of all the nations and monarchies, and give the same 
value to all religions, reducing all family connections, laws, and God to self-interest (Lopes da Veiga, 1641: 258-9). These principles scandalize Heraclitus, but Democritus finds explanations for them. According to him, Politicos are of two classes, either by position or by education. The former are actually worthy of praise because they carry out a function that is the most useful and necessary of all for the common good and the preservation and growth of communities. Regarding the theoretical Politicos, who "govern without being governors" that is, the Tacitists, who have no more law than what is convenient to themselves - , the situation is more complicated. In reality, they only err through excess, because they make known how the world is governed. It is true that they renounce friendship and the trust of other men, but they labour thinking of their own utility,

and, given how the world is, I tell you that they find less unpleasantness along the path of hiding their own breasts and examining those of others, than on the contrary path of trusting the treasures of their secret place to the contingency of some evil treatment, and using words to open up their heart, which provident Nature has hidden to the senses (Lopes da Veiga, 1641: 265). ${ }^{48}$

No man has ever been rejected for being a Politico; and, besides, the best course for getting and keeping friends is, if not deception, the "magic spell of benefices and good communication". ${ }^{49}$ In the end, Politicos are the men best suited to advance at court.

The impossibility of setting up history as an area of certain knowledge places Lopes da Veiga's thought in a singular position, determined, once again, by extreme skepticism. In this case, a comparison with Gassendi is once again significant: the latter has a notable relationship with the world of French historiography though his connection, for example, with Henri Estienne, Gabriel Naudé (former disciple of Cremonini), or Peiresc. His interest in the use of critical philological tools was crucial to his reading and recovery of Epicurus (Joy, 1987: 44-47), to the extent of setting up a system of proofs that combines empirical and historical arguments; a method that, in fact, was derived from a notion of continuity between nature and culture, and the relationship between the two (Joy, 1987: 165-194). At this point one can clearly see the relationship between Lopes da Veiga's epistemological skepticism and his political thought: the discontinuity between the natural and civil worlds justifies the impossibility of turning history into a scientific discipline; as does the strict separation that the "disenchanted" wise man sees in the world between the hidden inner realm of natural law and the vain exterior to which one must nevertheless conform. For Gassendi, the continuity between natural and civil law was dependent on a social contract that guaranteed forms of individual liberty. Unlike with Hobbes, this social contract was an extension of the natural state, to the extent that living in society was part of human nature (Sarasohn, 1996: 142-144). In a certain sense, this continuity determined Gassendi's position with regards to pol- itics: although no universal civil law exists, natural law has a universality that makes civil law not be entirely circumstantial and arbitrary. In this way, he was able to modify the Epicurean ethical principle of self-love and the pursuit of one's own happiness, relating it to the human need for socialization and for seeking the love of others (Sarasohn, 1996: 162-3). Lopes da Veiga, as we have seen, posits a net discontinuity between natural and civil law. The basis of politics is not a contract; rather, it is founded upon inequality: some man did something worthy of merit (or committed an injustice) and the advantageous position he gained by it was inherited by his descendants. In this way, Lopes da Veiga's extreme skepticism is different from that of Gassendi or Hobbes - or from other writers like Bodin, the representative by antonomasia of Politicos who, as a jurist, started from a position critical of Roman law (as a civil code exclusively for the Roman people, without universal value) in order to search for the logical form of a universal civil code that could be applied to all of humanity in order to construct an historical method (Gerbier, 2009). In his legal thought, Lopes da Veiga believed that law was created to restrain natural human evil, and that it was therefore necessary.

But since every Nation and Kingdom forms and adjusts this legality according to the capacity or whim of its Legislators, it turns out that not every Nation correctly obtains what it ought to have. And, once it sets out on the path of error and acquires the habit of it: no matter how much people may later gain experience and cry aloud at the disadvantages, the laws come to occupy an obligatory position, and come to be tolerated as unavoidable or unassailable, either because custom has made people feel at home with them, or because they venerate the Fathers who put them in place, as they would Religious Fathers, or because the present generation thinks it would be horrific to alter what has become old..$^{50}$

This can be clearly seen in the inheritance of Roman law, which is not workable in the present time. The abundance of decrees and norms, which attempt to adapt themselves to the plurality of cases and circumstances, does nothing more than encourage the cunning of lawyers, which multiplies the number of possible interpretations. All this results in "a greater confusion of Science", 51 with an infinite number of debates and controversies, in which knowing the truth is impossible (Lopes da Veiga, 1641: 238-240). But Lopes da Veiga keeps his distance also from a Catholic tradition of understanding human history that saw in it a source of theological truth, starting from the fact that trust in other human beings is the very basis of human society. This was the position of Melchor Cano, for example (Cano, 2006: 551ff), which of course depended on a notion of natural law quite different from that of Lopes da Veiga. For the latter, the philosopher should put into practice the moral principle of utility,

[...] lest they hide themselves, and so that he might have principles with which to guess at the underlying inten- 
tions that can exist in any interchange or communication, and to turn aside or prevent the evil intent of those with whom he is dealing; for if not trusting anyone is a characteristic of the evil Spirit, trusting everyone would seem to belong to the Simple spirit. And it is necessary to use Art to know how far Human Evil might extend, and to become knowledgeable in how the World works, in order not to perish miserably at the hands of the deceptions that are practiced (Lopes da Veiga, 1641: 330-1). ${ }^{52}$

It would be pointless to underline here the consequences of this problematic connection between nature and politics in a thinker like Hobbes.

In the end, Religion is what truly separates Lopes da Veiga from the political writers. The politicians, he writes, challenge both human and divine laws. Yet Lopes da Veiga himself, in his discourses, overtly side-steps "spiritual motives" proper to "Holy Churchmen" ("Sagrados Eclesiásticos Varones"), in order to concentrate exclusively on the temporal realm (Lopes da Veiga, 1641: 266). This is a singular exception: it places theology at the final frontier of thought in a way that does not actually see it as intervening in the world. What really was Lopes da Veiga's religious position?

Descartes, in his Metaphysical Meditations, begins with the need to prove by natural reason the existence of God and of the immortal soul, even though he has doubts about the actual scope of the rational, philosophical demonstration used by those who deny the soul's immortality. For his part, Lopes da Veiga begins with a single affirmation:

he who does not see his calamity for what it is will hardly feel it to be such, and he who recognizes no Sovereign Subject to be blasphemed will hardly be disturbed by the seriousness of his mental blasphemy [...]. No one is perturbed by what he does not believe in (Lopes da Veiga, 1641: 289). ${ }^{53}$

Nor will they feel "any fear of the First Cause", ${ }^{54}$ since they "know only Second Causes as the beginning and the end, unceasingly circular, of everything in Creation" (Lopes da Veiga, 1641: 289). ${ }^{55}$ This affirmation does not, for Lopes da Veiga, give way to a scientific demonstration of the existence of God (which he leaves in the hands of the "most learned men, $[\ldots]$ whose profession it is to treat of it [...]"); ${ }^{56}$ rather, it produces "Reason's pure indications and prudent conjectures" (Lopes da Veiga, 1641: 289), ${ }^{57}$ such as the typical argument from the perfection of the fabric of nature and humanity. Clearly, avoiding explicitly discussing "spiritual motives" makes clear the autonomy of the two realms, Theology and reason. The relationship between the two produces a conflict that can already be found in Montaigne, and whose interpretation has yielded the expression, "skeptical fideism", an aporia that can be precisely defined thus: faith represents, for a human being, a far horizon without any mystical implication; that is, it marks a frontier that serves to make clear what humanity's sphere of action is (Cardoso, 2009). This appears to be Lopes da Veiga's case, since he establishes a net separa- tion between the world of reason and the theological world. This is an argument developed, for example, by La Mothe Le Vayer, who tried to conciliate faith and skepticism by arguing that their spheres of action were totally different and that the Scriptures did not refer to the natural world. Jesus Christ himself had recommended "loüable ignorance" in keeping silent when Pilate asked him: "Quid est veritas?" (La Mothe Le Vayer, 1633: 135-136). Lopes da Veiga speaks in even more extreme terms about God: when arguing that differences of blood are natural facts, not political ones, he criticizes those who say that blood can be differentiated, which would imply "that republics, ministers, and princes have power and authority from nature or its Author to qualify and differentiate blood (which, if one looks at it clearly, neither nature itself nor even all the omnipotence of its Author can do, without making distinctions in the species)" (Lopes da Veiga, 1935: 36-7).58 The modern editor adds a note here saying that "the strange phrase [is] in parentheses in the margin. Someone else - perhaps out of fear - crossed it out with a double line in different ink". This phrase is loaded with meaning: the question of the divine will and its scope in the face of nature's laws was an old theological problem which nevertheless had acquire a new dimension at this period of the seventeenth century. This is evidenced by the debate between Gassendi and Descartes on divine omnipotence, published in 1647 as an appendix to the Méditations méthaphysiques. Descartes argued that it was impossible that God could alter eternal mathematical truths, and, therefore, that these were absolutely necessary. On his side, Gassendi took the consequences of God's "omnipotence" to its extreme: nature and its laws depend on God, and, therefore, he can alter them at any time (Osler, 1997). Lopes da Veiga seems to be closer to Descartes; this would explain, in addition, his own concept of mathematics as eternal truth, and of the necessity of the world. This leaves him in a religiously ambiguous position: he sets up de facto a separation between the worlds of reason and theology, but at the same time seems to believe in the radical necessity of the natural world.

\section{INTERIORITY AND SUBJECTIVITY}

What type of subject is the Lone Man at Court, retired from the world, living his truth at the margins of common opinion, yet conforming to the social institutions which he internally mocks? He is not, of course, the Lone Man of the Village portrayed by Antonio de Guevara, but neither is he the retired, spiritual contemplative - the sort of person from whom Lopes da Veiga explicitly detaches himself (Lopes da Veiga, 1935: 14). There exists a type of strangeness or marginality that has often been identified in Spanish historiography with the marrano, as Miriam Bodian argues in her article in this same monograph. In the end, the marrano's experience was one of distance between exterior and interior, between practice and belief. From this point of view, it has been possible to see marranismo as a radical experience of "unbelonging", exemplified in personalities like Spinoza, whose "marra- 
no subjectivity" and experience of not belonging either to the Jewish or the Christian world assumed, in its political expression, a democratic form (in contrast to Hobbes's Leviathan) that "destroyed the imperial foundations of Europe" (Villacañas, 2012). Nevertheless, it could be problematic to use the category of marrano in this sense, because it appears to create a link between political forms of not belonging and an ethnic identity. On the other hand, it is possible to reflect on the intellectual consequences of mass conversions in a society like Spain's when it comes to defining and conceptualizing forms of skepticism that, one way or another, were being produced and constructed throughout Europe in an era of dissimulation and of the experience of interchangeable identities under the appearance of confessional belonging. In large measure, as Foucault recalled, the problem of the "subject" in Early Modern Europe can be formulated as the problem of how to "make oneself a religious subject without mediation" (Libera, 2015: 19).

It is true that António Lopes da Veiga was accused of being a judaiser: for example, in some of the Conde de Villamediana's poems (Sánchez, 1961: 132-134, Acquier, 2000: 87). Although some credit may have been given to Lopes da Veiga's possible Jewish origins, this accusation really must be understood in the wider context of the Portuguese nation's history in Spain during this crucial period (Bouza, 2000) - a context that makes Lopes da Veiga's courtly career even more singular, and that constitutes a fundamental fact for his moral thought and the defining of his "disenchantment". This tension between the constitution of a social subject and the consolidation of modern political institutions has been understood in self-fashioning terms in studies about, for example, Galileo in his courtly career (Biagioli, 2008). For all their differences, the cases of Galileo and Lopes da Veiga reveal the fundamental role of the court for understanding the civilizing process and the establishment of disciplining mechanisms in Modern Europe.

Naturally, the hypertrophy of the problem of "conscience", with all its categories (doubtful, opinionated...), in moral literature can be linked to this disciplining process, which reflects the deep unity between a moral issue, on the one hand, and an epistemological one on the other. One word - "probable" - can help us to understand the essential unity of this epistemological-moral problem. Studies of the conscience, foundational for casuistry, expressed the need to apprehend the complexity of the moral world, and to attempt to submit the "conscience" to some authority in times of a crisis for dogmatism (Río Parra, 2008). It was not mere chance that the old category of the "doubtful conscience" grew and extended itself until occupying a central space in the world of moral probability, as in the case of Juan Caramuel, the prince of probabilists. This doubt is precisely what allowed for the appearance on the scene of forms of mediation, spiritual guidance, and religious authority.

The purely epistemological dimension of this moral problem comes into view when one tries to reflect on the problem of continuity between the natural and political worlds. Can human institutions and human history be the objects of scientific knowledge? Can propositions of universal value be established regarding human actions? Can universal moral or legal norms be established? Questions like these mark out the borders of a wide but crucial field. It is enough to remember the Foucaultian model, according to which the constituting of the modern European subject is parallel to the constituting of humanity as an object of knowledge. As we have seen, some, like Lopes da Veiga, established a net separation between the natural and the political worlds. Hobbes theorized, for example, about what type of scientific knowledge justified the development of a science of political rights and obligations, and about whether this type of science was the same as the one used to know the physical world. Even if Hobbes's solution to this problem of two types of science was unsatisfactory (Malcolm, 2002), there remains the question of the relationship between the definition of human passions and the possibility of thinking about a political subject. Lopes da Veiga's political subject — about which it is impossible to make any kind of universal judgement except his own evil - is definable only on the basis of complete conformity to the established order, not from any concept of justice or of a social contract. Here Lopes da Veiga's radical skepticism demonstrates its radical political conformism as well.

\section{ACKNOWLEDGEMENT}

The research leading to these results has received funding from the European Research Council under the European Union Seventh Framework Programme (FP7/20072013)/ ERC Grant Agreement number 323316, project CORPI "Conversion, Overlapping Religiosities, Polemics, Interaction. Early Modern Iberia and Beyond," IP: Mercedes García-Arenal

Partial English translation by Jonathan Nelson

\section{NOTES}

1 On the nature of Modernity as experience and interpretation see: Wagner (2008).

2 See also the contribution of Moshe Sluhovsky in this special issue.

3 "An exemplary linking of the revival of classical learning, the Protestant reformation and the rise of the new philosophy as stages in the liberation of the inquiring mind was set out in the Dictionnaire historique (1697) by Pierre Bayle" (Crombie, 1996: 36). For a continuation of this genealogy in current literature see Seigel (2005).

4 See Miriam Bodian's contribution to this special issue.

5 "I think it is important to see traces of the revival of ancient scepticism first in Spain before anywhere else in Europe, and possibly to link this with the intellectual crises occurring in late $15^{\text {th }}$-century Spain with the Conquest of Granada, the Expulsion of the Jews from Spain, the development of anti-Trinitarism in Spain, and the development of anti-rationalist Spanish mysticism" (Popkin, 1999: xxviii)

6 In this regard, it is important also to consider that those parallel responses shared a common tension between literal and allegorical interpretations (Shalev, 2012: 54)

7 In Ditchfield words: "Confessionalization and extra-European colonization should be seen essentially as (parallel) functions of modernization" (Ditchfield, 2013: 26). See also Alaoui (2006). 
8 "el juizio libre [...] mal se acomoda a discurrir por fe en las cosas humanas, i sólo la mayor probabilidad, hallada por sus mismas especulaciones, le podrá, en lo ambiguo, hazer parcial desta o aquella resolución".

9 "sólo al provecho propio i al daño ageno ".

10 "todo se nota. Todo se advierte. Todo se malicia".

11 "no hay conversación donde no se alegue como voz de oráculo lo que dixo aquel su sabio, donde no se prueve lo de que se habla con que el tal lo dixo".

12 "I no cae debaxo del género de lisonja el confesar en los términos políticos lo que la ley política pudo conceder en orden al buen govierno. De forma que en el interior se deve reír, con la ley natural que iguala a todos, $\mathrm{i}$ acomodarse el exterior a la civil que constituye las diferencias. I viene esta distinción a ser verdad, assí lo que se siente, como lo que se manifiesta, aunque acciones al parecer entre sí contrarias".

13 "I en quanto a los otros advertid que como en la Religión ay dos especies de culto, interior el uno i el otro exterior, ay también en los respetos i veneraciones humanas la misma división. La interior veneración bien confieso que sólo a la virtud, o intelectual o moral, la debe el sabio. Pero a la exterior, como sea moderada (supuesta la costumbre del mundo, que vos solo no bastaréis a corregir) os obligan la vida civil i la necesidad de conservaros"

14 "el gobierno político o el estilo de cada provincia [...] pero siempre el cuerdo i desengañado debe reservar, dentro de sí, el conocimiento recto de la verdad del ser de cada uno".

15 "tan gloriosa, según la razón política, es, según la natural, una brutalidad indigna de hombres. I el valor militar, según la misma, se deva antes llamar fiereza que valor".

16 "no contentándose con sujetar los cuerpos de los súbditos, se ha estendido a querer subordinar también los entendimientos i a persuadirnos que no sólo los devemos obedecer i servir con los miembros, mas aun con la razón, dando a todas sus determinaciones el mismo crédito que a las divinas, i con repugnancia muchas vezes d'éstas i de la ley natural en que se fundan".

17 "en las controversias no hay medio más apropósito que el hazerse temido, ya sea por la opinión de la suficiencia, ya por la azedía de las respuestas, ya por la desestimación de las objecciones $[$ sic $] "$.

18 "personas tenidas de todos los que las comunican por oráculos, no más de porque resuelven con confiança i tratan con menosprecio al que las contradize".

19 "los ordinarios concursos, juntas, academias i congregaciones cortesanas".

20 "juntas de diversas jerarchías de entendidos, no todos cultivados con estudios, sino mezcla de zánganos i de abejas; de legos, que llaman de buena razón, y de noticiosos [...]".

21 "aprenden allí unos principios, que les estuviera mejor nunca haverlos oído, i con ellos entran intrépidamente por todas las materias que se proponen".

22 "que oyen i callan si se altercan puntos de ciencia".

23 "la zumba i la chança, compuesta, las más vezes, de la cabriola del equívoco".

24 "pasan a determinar como de fe qualquiera proposición suya i a condenar como heréticas las de los otros".

25 "vozería y confusión babilónica".

26 "la ostentación de superioridad, o en los estudios o en el ingenio". On the topos of criticism of literary academies (King, 1963: 99-101).

27 “¿qué plaças o qué oficios se han proveído o se esperan proveer de nuevo?, ¿quáles, entre los del gobierno público, tengan mayores preeminencias i sean más dignos de ser apetecidos? ¿qué estilos se observen en los tribunales?”.

28 "como las questiones que suelen venir a plática son más comúnmente de facultades en que no hay demonstración mathemática, nunca le falta al ingenioso por donde escaparse, $i$ aun instar contra las conclusiones más admitidas de los doctos".

29 "El especular los secretos de Naturaleza, las Causas i Efetos de todo lo que contiene el Universo, en quanto curiosidad del Entendimiento i exercicio del Ingenio, no puede negarse que es loable; pero hazerlo ocupación principal, estimarse i desvane- cerse por ella, supuesta la incerteza de quanto se resuelve, i la poca utilidad que de semejante Estudio se sigue, no sólo tengo por indigno de alabança, mas a qualquiera luz que le mire, por instituto indignísimo de risa".

30 "yo llamo sabio, no al más especulado, sino al que sabe lo que más puede aprovecharle".

31 "saber los defetos de los linages agenos" or "consolar los del propio". Once again, we can interpret this phrase in the light of Lopes da Veiga's work as secretary to Bernardino Fernández de Velasco, and to the way that history was principally used in noble houses, to legitimise the record of the lineage - a use that could be at odds with other historiographical practices (Jular, 2014).

32 An argument that is only valid for human history, not for sacred history or the holy fathers.

33 "aun abstrayendo de la verdad o mentira de las relaciones".

34 "pompa vana, quando no sea de maligna curiosidad".

35 "arrogante turba de Gramáticos y Críticos [...] ignorante canalla i hezes $[. .$.$] de los literarios".$

36 "sobre letras, sílabas i dicciones, sin las quales no se puede escribir ni hablar, con poder para calumniar o aprobar, si no los concetos, las imágenes i expressión dellos, i para suplir o emendar los textos más auténticos".

37 "incapaz de penetrar lo interior de la Sabiduría".

38 "el imperio sobre las exterioridades".

39 "las significaciones de los vocablos, la pronunciación i acentos de las dicciones, los espacios de las sílabas, asonancias i disonancias, aspereza i blandura de las letras".

40 "profesión de principiantes perpetuos".

41 "fixos i permanentes a la entrada de la puerta del saber".

42 "disputar i reconocer lo íntimo de las sentencias, questiones i discursos científicos".

43 "emendar corrupciones de vocablos, alterar colocaciones, aprobar o reprobar lecciones de lugares" son tareas "que no salen del distrito de las palabras".

44 "desnaturalizando el ser y calidades de cada cosa, i haziendo que el objeto sea instrumento, i el instrumento objeto".

45 "Dos Filósofos Estoikos presento á V.E. en lengua Kastellana, tan axustados en librea de palabras i ortografía, komo ellos lo fueron en sus razones y kostumbres. El esterior por mi parte es éste, lo interior dizen sus eskritos [...]. Van alegres kon el traxe $\mathrm{i}$ ropa frugal i senzilla, komo fue su vida".

46 "tan contrarios de todo género de Fe, que aun a la Divina no conceden más que las apariencias inescusables a su conservación [...]. Con los mismos ojos con que miran las cosas terrestres, quieren divisar las superiores"

47 "goviernan sin ser governadores".

48 “i, según está el mundo, os digo que menos disgustos se le ocasionan por el camino de ocultar los senos del propio pecho i escudriñar los del ageno, que por essotro de fiar a la contingencia de algún mal trato los tesoros de su secreto, i trasladar a lo patente de las palabras el coraçón, que la próvida Naturaleza escondió a los sentidos"

49 "el hechizo de los beneficios i buena correspondencia".

50 "Pero como esta legalidad la guisa i acomoda cada Nación i cada Reyno, según la capacidad o capricho de sus Legisladores, sucede que no todas las Naciones aciertan a tener la que conviene. I una vez tomado el curso i adquirido hábito en el yerro, por más que después descubran las experiencias i publiquen a vozes los inconvenientes, o porque los domestica la costumbre, o porque los haze como Religiosos la veneración de los Pasados, que los aprobaron, o porque se les representa horrible a los presentes el alterar lo envejecido, vienen a pasar plaça de forcosos i a ser tolerados como inescusables o invencibles".

51 "confusión mayor de la Ciencia".

52 "[...] porque no se le escondan i tenga principios por donde conjeturar las segundas intenciones que en todos los tratos i comunicaciones puede aver, i desviar o prevenir las malicias de los que tratare, que si no el fiarse de nadie es de Ánimo maligno, el asegurarse de todos parecerá de Simple. I es necesario conocer por Arte hasta dónde suele estenderse la Maldad Humana, i enterarse de cómo en el Mundo se procede, para no perecer miserablemente a manos de los engaños que se usan”. 
53 "mal puede sentir su ruina el que no la tiene por tal, i mal desazonarse con representación alguna de la gravedad de la mental Blasfemia el que no reconoce Soberano Sujeto de quien blasfemar [...]. A nadie perturba lo que no cree".

54 "temor alguno de la Primera Causa".

55 "sólo a las Segundas Causas conocen por principio i fin, circularmente incesable, de todo lo Criado".

56 "los doctísimos varones, [...] cuya profesión es el tratarlo[...]". 57 sino "a puros indicios de Razón i conjeturas prudenciales".

58 "que tengan las repúblicas, los ministros i los príncipes poder i autoridad de la naturaleza o de su Autor para calificar i diferenciar la sangre (cosa que, apurándola bien, ni la misma naturaleza, ni aun toda la omnipotencia de su Autor, la puede hazer sin diferenciar la especie)".

\section{REFERENCES}

Acquier, Marie-Laure (2000) "Los tratados en prosa de Antonio López de Vega: aproximación al discurso político en el siglo XVII". Cuadernos de Historia Moderna, 24: 11-31.

Biagioli, Mario (2008) Galileo cortesano: la práctica de la ciencia en la cultura del absolutismo. Katz, Buenos Aires (Spanish translation of Galileo Courtier. The Practice of Science in the Culture of Absolutism, University of Chicago Press, Chicago, 1993).

Bireley, Robert (2007) "Redefining Catholicism: Trent and beyond". In The Cambridge History of Christianity: Reform and Expansion 1500-1660, edited by Po-Chia Hsia, R. Cambridge University Press, Cambridge: 145-161.

Boer, Wietse de (2001) The Conquest of the Soul: Confession, Discipline, and Public Order in Counter-Reformation Milan. Brill, Leiden.

Boyle, Robert (1690) The Christian virtuoso, shewing that by being addicted to experimental philosophy, a man is rather assisted than indisposed to be a good Christian. In the Savoy, Edward Jones for John Taylor-John Wyatt.

Bouza, Fernando (2000) Portugal no tempo dos Filipes. Política, cultura, representações (1580-1668). Cosmos, Lisboa.

Campanella, Tommaso (2004) L'ateismo trionfato, ovvero Riconoscimento filosofico della Religione Universale contra l'antichristianesmo macchiavellesco, edited by Ernst, Germana. Scuola Normale Superiore, Pisa.

Cano, Melchor (2006) De locis theologicis, edited by Belda, Juan. B.A.C., Madrid.

Cañete, Carlos and Torres, Jorge de (2017) "The Politics of Domination in Missionary and Royal Architecture". In The Archaeology of the Jesuit Missions in Ethiopia (1557-1632), edited by Fernández, V. M.; Torres, J. de; Martínez d'Alòs-Moner, A. and Cañete, C. (auths.). Brill, Leiden: 439-456.

Cardoso, Sérgio (2009) “On Skeptical Fideism in Montaigne's Apology for Raymond Sebond". In Skepticism in the Modern Age. Building on the Work of Richard Popkin, edited by R. Maia Neto, J.R., Laursen, J.C. and Paganini, G. Brill, Leiden: 71-82.

Carolino, Luís Miguel (2007) "Mathematics and the Late Aristotelian Theory of Science: The 'Quaestio de Certitudine Mathematicarum' in Seventeenth-Century Portuguese Universities”. In Más allá de la Leyenda Negra. España y la Revolución Cientifica. Beyond the Black Legend: Spain and the Scientific Revolution, edited by Navarro Brotóns, Victor and Eamon, William. Universitat de Valéncia-CSIC, Valencia: 399-411.

Clark, Stuart (1997) Thinking with Demons: the Idea of Witchcraft in Early Modern Europe. Oxford University Press, New York.

Crombie, Alistair C. (1996) Science, Art, and Nature in Medieval and Modern Thought. Hambledon Press, London.

Ditchfield, Simon (2004) "Of Dancing Cardinals and Mestizo Madonnas. Reconfiguring the History of Roman Catholicism in the Early Modern Period". Journal of Early Modern History, 8: 386-408.

Ditchfield, Simon (2013) "Tridentine Catholicism". In The Ashgate Research Companion to the Counter-Reformation, edited by Bamji, A., Janseen, G.H. and Laven, M. Ashgate, Surrey.

Eire, Carlos M. N. (2016) Reformations. The Early Modern World, 1450-1650. Yale University Press, New Haven, London.
Elias, Norbert (2000 [1939]) The Civilizing Process. Sociogenetic and Psychogenetic Investigations. Blackwell, Oxford.

Galán Melo, Sixto (1992) "Ideas ortográficas en Gonzalo Coreas". In Actas del II Congreso Internacional de Historia de la Lengua, edited by Ariza Viguera, Manuel and Cano Aguilar, Rafael, vol. 1, Asociación de Historia de la Lengua Española, Madrid: $265-272$.

García-Arenal, Mercedes (editora) (2013) “Taqqiya: Disimulo Legal". Al-Qantara, 34, 2: 345-546.

García-Arenal, Mercedes (2016) "Introduction". In After Conversion: Iberia and the Emergence of Modernity, edited by GarcíaArenal, M. Brill, Leiden: 1-18.

García Gómez, Ángel M. (1984) The Legend of the Laughing Philosopher and its Presence in Spanish Literature (1500-1700). 2nd ed., Servicio de Publicaciones de la Universidad de Córdoba, Córdoba.

Gerbier, Laurent (2009) "Une méthode pour interpréter les histoires: Machiavel et Jean Bodin". Revue de Métaphysique et de Morale, 62: 151-162.

Gracián de la Madre de Dios, Fray Jerónimo (1978) Diez lamentaciones del miserable estado de los atheístas de nuestros tiempos. In Beatus vir. Carne de hoguera. Constantino Ponce de la Fuente y Fray Jerónimo Gracián de la Madre de Dios. Editora Nacional, Madrid.

Hazard, Paul (1935) La crise de la conscience européenne, 16801715. Boivin et Cie, Paris.

Jones, Howard (1981) Pierre Gassendi's Institutio Logica, 1658. Van Gorcum, Assen.

Joy, Lynn Sumida (1987) Gassendi the Atomist. Advocate of History in an Age of Science, Cambridge University Press, Cambridge.

Jular Pérez-Alfaro, Cristina (2014) "La importancia de ser antiguo. Los Velasco y su construcción genealógica". In La memoria de los antepasados. La construcción de la nobleza en la Baja Edad Media, edited by Acosta, A.; Prieto Lasa, J. R. and Díaz de Durana, J.R. Marcial Pons, Madrid.

King, Willard F. (1963) Prosa novelística y academias literarias en el siglo XVII. Anejos del Boletín de la Real Academia Española, Madrid.

Korreas, Gonzalo (1630) Ortografía kastellana, nueva i perfeta [...], i eL Manual de Epíkteto i la Tabla de Kebes, filósofos estoikos. Xazinto Tabernier, Salamanka.

La Mothe Le Vayer, François de [Orasius Tubero] (1630) [1604] Quatre dialogues faits à l'imitation des anciens. Jean Sarius, Francfort.

La Mothe Le Vayer, François de [Orasius Tubero] (1633) [1606] Cinq autres dialogues du mesme auteur, faits comme les precedents à l'imitation des anciens. Jean Sarius, Francfort.

Libera, Alain de (2015) L'invention du sujet moderne. Cours du Collège de France 2013-1014. Vrin, Paris.

Lopes da Veiga, António (1641) Heráclito i Demócrito de nuestro siglo. Descrívese su legítimo filósofo. Diálogos morales sobre tres materias, la nobleza, la riqueza i las letras. Diego Díaz de la Carrera, Madrid.

Lopes da Veiga, António (1653) El perfeto señor, sueño político. Con otros varios discursos y últimas poesías. Gabriel de León, Madrid ( $1^{\circ}$ ed., Viuda de Alonso Martín, Madrid, 1526).

Lopes da Veiga, António (1935) Paradoxas racionales, escritas en forma de diálogos del género narrativo la primera, del activo las demás, entre un cortesano i un filósofo, edited by Buceta, Erasmo. Imprenta de la Librería y Casa Editorial Hernando, Madrid.

Magnard, Pierre (1987) "Pascal et le sens du vide". Baroque, 12. doi: 10.4000/baroque.580.

Malcolm, Noel (2002) "Hobbes's Science of Politics and his Theory of Science". In Aspects of Hobbes. Oxford University Press, Oxford: 146-155.

Maravall, José Antonio (1966) Antiguos y modernos: la idea de progreso en el desarrollo inicial de una sociedad. Sociedad de Estudios y Publicaciones, Madrid.

Martin, John (1997) "Inventing Sincerity, Refashioning Prudence: The Discovery of the Individual in Renaissance Europe". The American Historical Review, 102, 5: 1309-1342. 
Menéndez y Pelayo, Marcelino (1891) De los orígenes del criticismo y del escepticismo y especialmente de los precursores españoles de Kant. Establecimiento tipográfico de Ricardo Fe, Madrid.

Muir, Edward (2008) Guerre culturali. Libertinismo e religione alla fine del Rinascimento. Laterza, Roma-Bari: 48-54 (it. trans. of The Culture Wars of the Late Renaissance. Skeptics, Libertins and Opera. Harvard University Press, Cambridge, Mass.-London, 2007).

Núñez, César (2007) "Un solitario en la corte. Las Paradoxas racionales de Antonio López de Vega". Nueva Revista de Filología Hispánica, 55: 77-119.

Ocasar Ariza, José Luis (2015) "La palabra exiliada. El cronotopo como expresión de ideología anticultural". eHumanista, 29: 342-359.

Ong, Walter (1958) Ramus. Method, and the Decay of Dialogue. From the Art of Discourse to the Art of Reason. Harvard University Press, Cambridge, Mass.-London.

Osler, Margaret J. (1997) "Volonté divine et vérité mathématique: le conflit entre Descartes et Gassendi sur le statut des vérités éternelles". In Gassendi et l'Europa (1592-1792), edited by Murr, Sylvia. J. Vrin, Paris: 31-41.

Paganini, Gianni (2008) Skepsis. Le débat des modernes sur le scepticisme. Montaigne-Le Vayer-Campanella-HobbesDescartes-Bayle. Librairie Philosophique J. Vrin, Paris.

Pastore, Stefania (2004) Un'eresia spagnola: Spiritualità conversa, alumbradismo e inquisizione. L. S. Olschki, Florence.

Popkin, Richard H. (1999) "Introduction. Warts and All, Part 2". In Everything Connects: In Conference with Richard H. Popkin. Essays in his honor, edited by Force, J.E. and Katz, D. S. (editors.). Brill, Leiden: xi-lxxvi.

Popkin, Richard H. (2003 [1960]) The history of scepticism: from Savonarola to Bayle. Rev. and expanded ed. Oxford University Press, Oxford.
Prosperi, Adriano (1996) Tribunali della coscienza: inquisitori, confessori, missionari. G. Einaudi, Torino.

Río Parra, Elena del (2008) Cartografías de la conciencia española en la Edad de Oro. Fondo de Cultura Económica, México.

Robbins, Jeremy (2007) Arts of Perception. The Epistemological Mentality of the Spanish Baroque, 1580-1720. University of Glasgow-Routledge, Glasgow-London-New York.

Sánchez, José (1961) Academias literarias del Siglo de Oro español. Gredos, Madrid.

Sarasohn, Lisa T. (1996) Gassendi's Ethics. Freedom in a Mechanistic Universe, Cornell University Press, Ithaca.

Seigel, J. E. (2005) The Idea of the Self: Thought and Experience in Western Europe Since the Seventeenth Century. Cambridge University Press, Cambridge.

Shalev, Zur (2012) Sacred Words and Worlds: Geography, Religion, and Scholarship, 1550-1700. Brill, Leiden.

Sluhovsky, Moshe (2013) "St. Ignatius of Loyola's Spiritual Exercises and their contribution to Modern Introspective Subjectivity". Catholic Historical Review, 99, 4: 649-674.

Sosa, Manuel de Faría (1674) Noches claras, divinas y humanas flores. Antonio Craesbeeck de Mello, Lisboa.

Vieira, Antônio (2001) As lágrimas de Heráclito. Texto original italiano do padre Antônio Vieira, com tradução portuguesa de época e proposição do padre Girolamo Cattaneo em apêndice, edited by Salomão, Sonia N.. Editora 34 Ltda., São Paulo.

Villacañas, José Luis (2012) "Spinoza: democracia y subjetividad marrana". Política común. doi: http://dx.doi.org/10.3998/ pc. 12322227.0001 .003

Wagner, P. (2008) Modernity as experience and interpretation: a new sociology of modernity. Polity, Cambridge, UK.

Weber, Max (1930 [1905]): The Protestant Ethic and the Spirit of Capitalism. Trans. by Talcott Parsons. Charles Scribner, New York. 